UDC 378:656.61

\title{
OVERVIEW OF TRAINING PROGRAMS FOR MIDSHIPMEN IN THE USA
}

A. Linetskaya,

JD (Juris Doctor), assistant

Cardozo Law School, New York City, USA

L. Kosharskaya,

CDTechn, docent, docent of the department of «Ship repair»

G. Makhurenko

DEcon, professor, Head of the Department of Entrepreneurship

makhurenko@mail.ru

Odessa National Maritime University, Odessa, Ukraine

Abstract. The international maritime community systematically introduces ever higher standards of quality training of marine specialists capable of professional growth and rapid conversion for the operation of modern vessels of all types.

At the heart of $84 \%$ of emergency cases are errors due to insufficient competence of specialists, managers of the ship and operating ship power plants and systems. The basic level of training is reduced, seafarers lack practical skills. To remain a maritime power, competitive in the training of qualified specialists at all levels, manage the modern fleet and effectively operate it, it is necessary to improve the system of maritime education without delay. The work provides an overview of training programs for midshipmen in the United States.

Keywords: marine specialist, practice program, marine education.

\section{ОГЛЯД ПРОГРАМ НАВЧАННЯ ДЛЯ КУРСАНТІВ У США}

\author{
А. Линецька, \\ д.ю.н., асистент \\ Кардозька юридична школа, Нью-Йорк, США \\ Л. Кошарська \\ к.т.н., доцент, доцент кафедри «Судноремонт» \\ Г. Махуренко \\ д.е.н., професор, зав. кафедри «Підприємництво»
}

Одеський національний морський університет, Одеса, Украйна

Анотація. Міжнародне морське співтовариство планомірно вводить все більш високі стандарти якості підготовки морських фахівиів, здатних до професійного росту $i$ швидкого перепрофілювання для експлуатації сучасних суден всіх типів.

В основі $84 \%$ аварійних випадків лежать помилки, пов'язані з недостатньою компетенцією фахівців, які керують судном і експлуатують суднові енергетичні установки та системи. Знижується базовий рівень підготовки, у моряків бракує практичних навичок.

(C) Linetskaya A., Kosharskaya L.V., Makhurenko G., 2017 
DEVELOPMENT OF MANAGEMENT

AND ENTREPRENEURSHIP METHODS

ON TRANSPORT, № 4(61), 2017
РОЗВИТОК МЕТОДІВ УПРАВЛІННЯ

ТА ГОСПОДАРЮВАННЯ

НА ТРАНСПОРТІ, № 4(61), 2017

Щоб залишатися морською державою, конкурентоспроможною в підготовці кваліфікованих фахівців усіх рівнів, управляти сучасним флотом $i$ ефек-тивно його експлуатувати, необхідно невідкладно удосконалити систему мор-ської освіти. В роботі дається огляд програм навчання курсантів в США.

3 огляду на морську освіту в Академї торгового флоту Сполучених Штатів (USMMA), в роботі відображені вимоги до морській практиці курсантів. Курсанти USMMA повинні завершити два морських періоду протягом чотирьох років навчання. Перший морський період триває приблизно 135 днів. Протягом иього періоду курсант прикріплюється до різних типів вантажних суден. Потім курсант повертається в Академію, щоб використовувати в навчанні свій досвід в море. Другий морський період довший, приблизно 265 днів. Протягом иього періоду курсант закінчує своє навчання на морській службі протягом 300 днів на борту морських суден $і$ завершує стажування в компанією або організаиії в рамках участі в транспортній або морської інженерної сфері. Другий період включає дво-шеститижневу стажування на березі, в залежності від вимог магістратури, щяоб забезпечити можливість спостерігати $і$ брати участь в операціях управління морської, транспортної або інженерної організації. Курсант приймає власне рімення щуодо того, де проходитимуть стажування. Залежно від області спеціальності і інтересу курсанта, він може бути направлений в судноплавну компанію, на суднобудівну верф, судноремонтний завод, на суднову брокерську або фрахтову фірму, в стивідорну компанію, морську інспекційну службу, компанію з буксирування, на портовий (термінальний) об'єкт або аналогічне підприємство.

Ключові слова: морський фахівецьь, програма практики, морська освіта.

\title{
ОБЗОР ПРОГРАММ ОБУЧЕНИЯ ДЛЯ КУРСАНТОВ В США
}

\author{
А. Линецкая, \\ д.ю.н., ассистент \\ Юридическая школа Кардозо, Нью-Йорк, США \\ Л. Кошарская \\ к.т.н., доцент, доцент кафедри «Судоремонт» \\ Г. Махуренко \\ д.е.н., професор, зав. кафедрой «Предпринимательство» \\ Одесский национальный морской университет
}

\begin{abstract}
Аннотация. Международное морское сообщество планомерно вводит все более высокие стандарты качества подготовки морских специиалистов, способных к профессиональному росту и быстрому перепрофилированию для эксплуатации современных судов всех типов.

В основе $84 \%$ аварийных случаев лежат очибки, связанные с недостаточной компетенцией специалистов, управляющчи судном и эксплуатирующчих судовые энергетические установки и системы. Снижается базовый уровень подготовки, у моряков не хватает практических навыков. Чтобы оставаться морской державой, конкурентоспособной в подготовке квалифицированных спеииалистов всех уровней, управлять современным флотом и эффективно его эксплуатировать, необходимо безотлагательно усовершенствовать систему морского образования. В работе дается обзор программ обучения курсантов в США.

Ключевые слова: морской специалист, программа практики, морское образование.
\end{abstract}


Problem statement. The profession of seafarers is unique, as they must not only comply with the requirements for the safety of navigation and life at sea, but also work in international crews, observing international watchkeeping requirements, organization of vessel maintenance and interaction in regular and extreme situations. In this regard, back in 1978, the Convention on the Preparation and Certification of Seafarers and Watchkeeping and the Codex-Appendix 1 to the Convention, which regulate the minimum requirements for the knowledge and skills of seafarers, were adopted.

These requirements are periodically «amplified» in the light of new requests for practice. And maritime states are obliged to eliminate the emerging inconsistencies in their education systems. And in connection with the fact that the above-mentioned documents regulate the minimum requirements, it is more correct to assess not the fact of reaching the regulatory minimum, but the level of excess of this minimum, that is, the «buoyancy reserve» of the national education systems.

It seems relevant to analyze the problems of the national maritime education system through the prism of general international requirements for the education system.

Review of the last research and publications. Since 1959, the International Maritime Organization (IMO) is the only specialized agency of the United Nations engaged exclusively in maritime navigation. IMO creates a forum for cooperation between Governments in the field of national regulations and practices relating to all types of navigation in international trade. This facilitates the adoption of comprehensive multilateral treaties for a wide range of technical measures and, in particular, the adop- tion of the highest practical standards aimed at improving the safety and efficiency of shipping in international trade [1].

The International Convention for the Safety of Life at Sea [2] (SOLAS), in its consistently published forms, is perhaps the most important of all international agreements on the safety of merchant ships. Each ship that makes an international voyage and is subject to this normative document [7] must comply with its requirements. Otherwise, it may be delayed, and for some positions ISPS (Code) [7] and not allowed to the port. The current version of the document is known as SOLAS-74.

The International Safety Management Code (ISM) was adopted on November 4, 1993 at the 18th Session of the IMO Assembly [3]. The main conclusion from the results of the studies was the lack of a system for managing the safe operation of ships and preventing pollution, as well as the inadequate preparedness of crews for actions in emergency situations. The practical result of the conducted studies was the development and implementation of various national and international recommendations as well as normative documents that are mandatory for implementation.

It is noted in [4] that in recent years the marine industry has faced numerous changes and problems. Most of them have created new requirements for knowledge levels and staff understanding of the problems that are working on the ground, especially for those at the management level. The safety of maritime activities is one of the areas associated with the complication of the maritime profession and the need for new knowledge. A very important aspect of the training process for training seafarers is to raise staff 
awareness of the new challenges of the time.

To this end, educational institutions involved in training are required to develop and offer qualified courses that cover the most recent requirements. The Maritime University in Constanta (Romania) and the Maritime Academy in Varna (Bulgaria) decided to develop a master's program dedicated to raising the awareness of maritime personnel in security matters. This program was developed with the support of IAMU and The Nippon Foundation in Japan. This document presents the aims and objectives of the MARSA project - raising awareness of the safety of maritime personnel and ways to implement them through the developed training materials and evaluation methods. The program includes such topics as maritime safety, navigation safety, risk-based safety, security knowledge in piracy zones, special operations of ships.

The paper [5] deals with the US National Maritime Security Strategy. It brings together all programs and initiatives in the field of maritime safety of the federal government into integrated and integrated national events with the participation of relevant departments, sectors and other areas. In addition to this Strategy, the Departments developed eight supporting plans to address specific threats and problems of the marine environment. Although the plans address various aspects of maritime security, they are interrelated and reinforce each other. Supporting plans include:

- national plan to raise awareness of the marine domain;

- a global plan for the integration of maritime intelligence;

- temporary response plan for sea operational threats;

- international advocacy and coordination strategy;
- marine infrastructure restoration plan;

- security plan for the maritime transport system (the plan is based on the call for recommendations on improving the national and international regulatory framework for the maritime region);

- security plan for maritime trade (the plan is based on a comprehensive security plan for the marine supply chain);

- internal plan (the plan is based on an internal information and propaganda plan that does not include federal materials to assist in the development and implementation of maritime security systems).

In [6] the question of possible insurance of the risk of damage to the berthing facilities as a result of their interaction with ships is being investigated.

In [7], the main document defining the requirements for development of the estuary port of Ust-Dunaisk (Ukraine) is the Memorandum of Understanding regarding the development of the Pan-European Transport Corridor VII (Danube). In accordance with the Memorandum of Understanding in the framework of the development of the port of UstDunaisk, the following topics should be considered:

- the state of the port and corridor infrastructure;

- assessment of safety requirements for navigation;

- the overall concept of coordinated development of the port and corridor;

- the necessary conditions for the participation of international financial institutions and the private sector in the development of both the port and corridor (Romania);

- organizational, legal, economic and social problems. 
The paper [8] notes the role and importance of maritime transport safety, which is a very important, systemic concept affecting all elements of the marine industry. However, the management of safety and its introduction into the maritime industry is now more important than ever. The modern maritime industry has a number of codes, conventions and guidelines that establish the boundaries of safety and efficiency of navigation. Development of the marine industry has led to a significant development of technologies, structures, dimensions, propulsion and safety of ships. At the same time, the development of new technologies in the marine industry has made changes in the education system.

Despite the great breakthroughs in technology and security, the marine industry is still a relatively dangerous place to work. The present study presents the flow and analysis of the development of technologies, which are important milestones for navigation with respect to their contribution to maritime security. The paper also discusses important factors that adversely affect the safety of navigation.

The paper [9] is aimed at studying the effect of the marine management model on the organizational effectiveness of shipping companies. For this purpose, a survey was conducted in the collection of data from shipping companies around the world. The hypotheses of this study were tested using modeling methods. It was found that the proposed model has a direct positive impact on security, business sustainability and its effectiveness.

The analysis of the main problems and tasks of ensuring safety in the field of navigation made it possible to formulate:

- determination of the navigation safety, as activities related to the protection of life and health of crew members of ships and passengers, the safety of the vehicles themselves and the goods carried thereon;

- determination of a ship security management system, as a set of documented measures necessary for the effective implementation of maritime safety requirements on ships.

Ensuring the safety of navigation is achieved through the implementation of the state policy in the field of security, a system of organizational, economic, technical and other measures on a planned basis, adequate to threats to the vital interests of the individual, society and the state.

Tasks of research. The aim of the work is to analyze the survey of marine education in the United States. This analysis is carried out for maritime educational institutions.

The basic material of research. Considering marine education in the United States Merchant Marine Academy, we should first of all dwell on the marine practice of cadets (midshipman). USMMA cadets must complete two sea periods during the four years of studying. The first sea period lasts approximately 135 days. During this period, the cadet is assigned to different types of dry cargo vessels. The cadet then returns to the Academy to build on his/her experiences at sea.

The second sea period is longer, roughly 265 days. During this period, the Midshipman finishes his/her sea service requirement of 300 days aboard ocean going vessels and completes an internship with a company or organization with involvement in the transportation or marine engineering industry. The second sea period includes a two-to six-week internship assignment ashore, depending on the Midshipman's major, to provide the opportunities to observe and participate in the management operations of a 
maritime, transportation, or engineering related organization. The Midshipman makes his/her own decision regarding where to do the internship. Depending upon a Midshipman's field of specialty and interest, the Midshipman may be assig-ned to a shipping company, shipyard, ship repair facility, ship brokerage and chartering firm, stevedoring firm, marine surveyor's office, towing company, port and terminal facility, or a similar enterprise. Optional internship assignments are also available with shore-based commands of the U.S. Armed Forces.

Midshipmen are given a number of courses called the «Sea Project» which, in addition to their shipboard duties, they are required to complete and submit for evaluation and grading (see below the actual courses and their descriptions, table 1). In addition to written assignments, Midshipmen take oral and written examinations after returning from sea. Aboard ship, marine transportation majors are assigned to the vessel's Deck Department.

Marine Engine for Deck Project. This sea project is designed to provide deck Midshipmen with an overview of the ship's mechanical and electrical systems. The object is to provide them with enough knowledge on how the ship functions to make them better ship's officers. The study focuses on equipment or systems that tend to affect the operation of the ship.

Cargo Operations 1. Using the ship as a laboratory, the objective of this sea project is for the Midshipman to acquire the knowledge of safe and efficient stowage and handling of cargo necessary to successfully perform the duties of a ship's licensed deck officer.

Integrated Navigation Systems 1. The Purpose of this first sailing period sea project is to serve as a guide for acquiring an in depth knowledge of the electronic navigation equipment and its integration with the navigateonal procedures encountered aboard the Midshipman's assigned vessels. The project emphasizes practical use of the equipment and reinforces the knowledge and skills acquired during the in-residence Integrated Navigation 1 course. The combination of the in-residence course and this sea project provides a strong foundation for the Midshipman to effectively assist vessel's watch standing officers, and as preparation for further training at the Academy.

Seamanship 1. The objective of this sea project is for the Midshipman to acquire the knowledge and practices of seamanship necessary to successfully perform the duties of a ship's licensed deck officer. Using the ship as a laboratory, this portion of the Sea Project will build upon the Midshipman's knowledge of seamanship terminology, practices and procedures gained from in-residence course work.

Ship Structure and Stability 1. Using the ship as a laboratory, this portion of the Sea Project curriculum will build upon the Midshipman's knowledge of ship structure, nomenclature, use of the ship's hydrostatic table and the determination of transverse stability gained from in-residence course work.

Navigation 1. The objective of this sea project is for the Midshipman to acquire the navigational skills and techniques required to properly perform the duties of a licensed deck officer. 
Marine Transportation / Maritime Logistics \& Security: Required Sea Projects

\begin{tabular}{|c|c|c|}
\hline & $\begin{array}{c}\text { Marine } \\
\text { Transportation }\end{array}$ & $\begin{array}{c}\text { Maritime Logistics } \\
\text { and Security }\end{array}$ \\
\hline \multicolumn{3}{|c|}{ First Sea Period (135 days) } \\
\hline Marine Engine for Deck Project & $*$ & * \\
\hline Cargo Operations 1 & $*$ & $*$ \\
\hline Integrated Navigation Systems 1 & $*$ & $*$ \\
\hline Seamanship 1 & $*$ & $*$ \\
\hline Ship Structure and Stability 1 & $*$ & $*$ \\
\hline Navigation 1 & $*$ & $*$ \\
\hline Navigation Law 1 & $*$ & $*$ \\
\hline Maritime Communications Sea Project & $*$ & $*$ \\
\hline \multicolumn{3}{|l|}{ Second Sea Period (265 days) } \\
\hline Cargo Operations 2 & $*$ & $*$ \\
\hline Integrated Navigation Systems 2 & $*$ & $*$ \\
\hline Seamanship 2 & $*$ & $*$ \\
\hline Ship Structure and Stability 2 & $*$ & $*$ \\
\hline Navigation 2 & $*$ & $*$ \\
\hline Navigation Law 2 & $*$ & $*$ \\
\hline Maritime Business & $*$ & $*$ \\
\hline Humanities Sea Project & $*$ & $*$ \\
\hline Internship & $*$ & $*$ \\
\hline Navigation 2 & $*$ & $*$ \\
\hline Navigation Law 2 & $*$ & $*$ \\
\hline Maritime Business & $*$ & $*$ \\
\hline Humanities Sea Project & $*$ & $*$ \\
\hline Internship & $*$ & $*$ \\
\hline
\end{tabular}

This is to be achieved by the shipboard practice and computations learned from in-residence courses in terrestrial navigation and composing essays on STCW watch keeping principles and commonly utilized navigation publications. These training activities will prepare the Midshipman for 2nd sailing and the capstone navigation classes in First Class Year and ultimately the USCG Third Mate's Exam.

Navigation Law 1. The objective of this sea year project is for the Midshipman to acquire the knowledge and practices of seamanship necessary to successfully perform the duties of a ship's licensed deck officer. Using the ship as a laboratory, this portion of the Sea Project will build upon the Midshipman's knowledge of seamanship terminology, practices and procedures gained from in-residence course work.

Maritime Communications Sea Project. The purpose of this first sailing period sea project is to serve as a guide for acquiring an in-depth knowledge of the electronic communications equipment found aboard modern commercial vessels. The project emphasizes practical use of the equipment and reinforces the knowledge and skills acquired during the in-residence maritime communications course. The com- 
bination of the in-residence course and this sea project provides a strong foundation for the Midshipman to work effectively as a GMDSS radio operator.

Cargo Operations 2. Using the ship as a laboratory, the objective of this sea project is for the Midshipman to acquire the knowledge of safe and efficient stowage and handling of cargo necessary to successfully perform the duties of a ship's licensed deck officer.

Integrated Navigation Systems 2. The purpose of this second sailing period sea project is to serve as a guide for acquiring a in-depth knowledge of the electronic navigation equipment and its integration with the navigational procedures encountered aboard the Midshipman's assigned vessel. The project emphasizes practical use of the equipment and reinforces the knowledge and skills acquired during the in-residence Integrated Navigation 2 course. The combination of the inresidence course and this sea project provides a strong foundation for the Midshipman to effectively assist the vessel's watch standing officers, and as preparation for further training at the Academy.

Seamanship 2. The objective of this sea course is for the Midshipman to acquire the knowledge and practices of seamanship necessary to successfully perform the duties of ship's licensed deck officer. In addition to basic seamanship subjects, advanced to-pics such as ship handling and contingency management are incorporated into this project. The course culminates with an oral exam upon return from sea.

Ship Structure and Stability 2. Using the ship as a laboratory, this portion of the Sea Project curriculum will build upon the Midshipman's knowledge of ship structure, nomenclature, use of the ship hydrostatic table and the determination of transverse and longitudinal stability gained from in-residence course work as well as during the first sailing.

Navigation 2. To acquire the navigational skills and techniques required to properly perform the duties of a licensed deck officer. This is to be achieved by the shipboard practice and computations learned from in-residence courses in celestial and terrestrial navigation and meteorology as well as creating voyage plans and composing essays on STCW watch keeping principles and commonly utilized navigation publications.

Navigation Law 2. The objective of this sea project is for the Midshipman to acquire the knowledge and practices of Navigation Law necessary to successfully perform the duties of a ship's licensed deck officer. The project concentrates on examining the major differences between the International and Inland Navigation Rules. The project will build upon the knowledge gained from in-residence course work and the first sailing period.

Maritime Business. This course is designed to both introduce the Midshipman to the business side of maritime operations and to provide an understanding of the total transportation network of which ocean shipping is a part. Midshipmen are required to research information and practices abo-ard their ship(s) to answer questions concerning this topic.

Humanities Sea Project. The Humanities Sea Project is designed to serve as a companion during the second «Sea Year» and to challenge students to think about their place, on ship and on shore, in the larger maritime world and explore their relationship with and understanding of other cultures and societies. As such, it serves the humanist goal of intellectual self-discovery; and through a series of 
rea-dings and writing exercises spaced out over the time at sea students will be able to «map» their individual voyages and personal journeys.

Internship. This program provides each Midshipman an opportunity to observe the management environment in an Academy mission (maritime, transportation, engineering, government agency, Armed Forces, etc.) related organizations for the periods of two weeks. Ranging from a basic survey to participation in executive, mid-and entry-level management projects, the Midshipman's choice of an internship requires investigation of the organization's background and history; current organizational structure; decision-making processes; operating procedures; and work place ethics. The Midshipman demonstrates in a written report a comprehension and understanding of these factors as well as basic management concepts as applied to the host organization.

Conclusions. A seamanship laboratory is maintained and operated by departmental faculty. The faculty also provides hands-on training in ship operations utilizing the vessels and dockside facilities of the Waterfront Training \& Operations Department. An important component of deck officer training is achieved through the use of a Full Mission Visual Bridge Shiphandling Simulator (VBSS), loca-ted in the Computer Aided Operations Research Facility (CAORF).

VBSS provides the bridge watch team with a visual representation of various harbors as seen from the bridge of a vessel, including landmasses, navigational aids, traffic ships and miscellaneous buildings and structures. Realistic radar images, fathometer readings, and audio cues (depicting ship sounds, buoy sounds, and en- vironmental and weather-related sounds) aid in completing the scene. The system is capable of introducing malfunctions and or failures to any of the equipment including the engine and steering systems. The system realistical lypresents the total marine scene and is primarily used for the training of Bridge Resource principals. It is also used to support other ship handling and navigation courses offered at the Academy.

In addition to VBSS, Midshipmen take advantage of various interactive integrated navigation and maritime communications simulators; tanker, container, and port loading simulators; and navigation laboratories. The simulators offer numerous ship models and geographic areas complete with visual presentations. Students interact with up to 50 contacts and maneuver through simulated land databases utilizing fully integrated bridge electronics and Electronic Chart Display Information Systems (ECDIS). All labs have the same fully integrated navigation simulation software package installed. Each lab is designed to run any combination of interacting own ships, depending on the exercise design.

The system provides a realistic display of all weather conditions, various atmospheric phenomena, and time of day, visibility and illumination effects, reflection, and glare on the water. Tides and currents can also be adjusted, as needed, and programmed to change during the simulation with buoys generating current feathers. In addition to the overall condition parameters, environmental zones can also be set-up to create such conditions as fog banks, local wind, current effects, and local wave effects. 


\section{Список литературы}

1. Томилина С.Н. Особенности обучения и воспитания курсантов морских вузов в постсоветских республиках / С.Н. Томилина // Научный журнал КубГАУ. - Кр: КубГАУ. - № 113(09), 2015. - С.5-

2. Кұлюжная Т.В. Повышение эффективности системы качества образовательных услуг путем внедрения нового учебного курса / Т.В. Калюжная, Н.В. Савкин // Вісник СевНТУ: Зб. наук. прачь. Севастополь: НТУ. - Вип. 138. Серія: Економіка і фінанси. - 2013. C.65-71.

3. Репетей В.Д. Пути повышения профессионализма в наииональной системе поиска и спасания на море / В.Д. Репетей // Судовождение. Shipping \& Navigation: Науково-технічний збірник. - Одесса: ОНМА. - Bbin.17. - 2009. - C.155-164

4. Международная конвенция по поиску и спасанию на море 1979 года - Одесса: Издатинформ, 2006. - 35с.

5. Немиев О.В. Подготовка морских специиалистов в вузе / О.В. Немиев [Electronic resource]. - Availableat: |www/URL: https: // cyberleninka.ru/article/n/podgotovka-morskih-spetsialistov-v-vuze.pdf

6. Kosharskaya L. Application of the system approach to the development of the project of a safety management system for navigation in Ukraine [Text] / L. Kosharskaya, G. Makhurenko, M. Postan // Technology audit and production reserves. - 2017. - Vol. 4. - № 2(36). P. 29-36. - Doi:10.15587/2312-8372.2017.109094

\section{References}

1. Tomilina, S.N. (2015). Osobennosti obucheniya i vospitaniya kursantov morskikh vuzov $v$ postsovetskikh respublikakh [Features of training and education of cadets of marine universities in the post-Soviet republics]. Nauchnyy zhurnal KubGAU - Scientific Journal of KubSAU, № 113(09), 5-17 [in Russian].

2. Kalyuzhnaya, T.V. (2013). Povysheniye effektivnosti sistemy kachestva obrazovatelnykh uslug putem vnedreniya novogo uchebnogo kursa [Increasing the effectiveness of the quality system of educational services by introducing a new training course]. Visnik SevNTU - Bulletin of SevNTU, 138. Seriya: Ekonomika i finansi, 65-71 [in Russian].

3. Repetey, V.D. (2009). Puti povysheniya professionalizma $v$ natsionalnoy sisteme poiska i spasaniya na more [Ways to improve professionalism in the national system of search and rescue at sea]. Sudovozhdeniye - Shipping \& Navigation, 17, 155-164 [in Russian].

4. Mezhdunarodnaya konventsiya po poisku i spasaniyu na more 1979 goda [International Convention on Maritime Search and Rescue, 1979]. Odessa, 35 [in Russian].

5. Nemtsev, O.V. Podgotovka morskikh spetsialistov v vuze [Training of marine specialists in the university] Retrieved from |www/URL: https: // cyberleninka.ru/article/n/podgotovka-morskih-spetsialistov-v-vuze.pdf [in Russian]. 
6. Kosharskaya, L. (2017). Application of the system approach to the development of the project of a safety management system for navigation in Ukraine [Text]. Technology audit and production reserves, Vol. 4, № 2(36), 29-36. - Doi:10.15587/2312-8372.2017.109094 [in English].

Стаття надійшла до редакиії 12.12.2017

\section{Рецензент:}

доктор філософії з економіки та логістики Технологічного університету Західної Померанії, Щецин, Польша Л.С. Філіна-Давидович

доктор економічних наук, професор, академік Транспортної академії України і міжнародної академії наук екології, безпеки людини і природи, член Американського математичного товариства, завідувач кафедри «Менеджмент i маркетинг» Одеського національного морського університету М.Я. Постан

Reference a JournalArticle/ Посилання на статтю: Overview of training programs for midshipmen / A. Linetskaya, L.V. Kosharskaya, G. Makhurenko // Development of administration and economic management methods on transport: Collection. - 2017. - № 4(61). - C. 88-98. 